\title{
腹腔鏡下に摘出できた子宮頸部Gartner管囊胞の一例
}

宮崎善仁会病院婦人科 ${ }^{1)}$ 、宮崎大学医学部附属病院産科婦人科 ${ }^{2}$

米田由香里 ${ }^{1)}$ 、和田俊朗 ${ }^{1)}$ 、福島和子 ${ }^{2)}$ 、鮫島 浩 $^{2)}$

\section{A case of Gartner's duct cyst arising from the cervix resected by laparoscopic surgery}

\author{
Yukari Komeda ${ }^{1)}$, Toshiro Wada $^{1)}$, Kazuko Fukushima ${ }^{2)}$, Hiroshi Sameshima ${ }^{2}$ \\ Miyazaki Zenjinkai Hospital ${ }^{1}$, \\ Department of Obstetrics and Gynecology, University of Miyazaki ${ }^{2}$
}

\begin{abstract}
Gartner's duct cysts are dilated Wolffian duct remnants commonly found in the lateral part of the vagina. We report a case of Gartner's duct cyst arising from the cervix, which was resected laparoscopically.

A 13-year-old girl complained of lower abdominal pain. An ultrasound scan revealed a pelvic tumor and MRI showed a $3.8 \times 4 \mathrm{~cm}$ cervical cyst. There were no malformations in the uterus or kidneys. The cyst was diagnosed as a Gartner's duct cyst arising from the cervix. The patient underwent laparotomy, and the cyst was found in the upper side of the right sacrouterine ligament. Visibility was limited by the narrow surgical incision, and resection of the cyst was difficult. The cyst was aspirated, and the contents were negative for malignancy. Several months postoperatively, the patient had a recurrence of the pain. Treatment options were laparoscopic surgery, marsupialization, and sclerotherapy. On operation, we incised the serosa of the cyst and peeled it off from the surrounding area. The cyst was connected to the cervical canal, and the defect in the cervical canal that resulted from its resection was sutured. The patient was pain-free after laparoscopic surgery. We suggest that Gartner's duct cyst arising from the cervix and protruding toward the pelvic cavity is a potential candidate for laparoscopic resection.
\end{abstract}

Key words: Gartner's duct cyst, cervical cyst, Laparoscopic surgery

\section{緒言}

Gartner管は、胎生期のWollff管が腟や子宮頸部 に遺残したものであり、それが囊胞化したものを Gartner管囊胞（Gartner's duct cyst, GDCと略す） という。同側の腎低形成やMüller管の重複奇形を ともなうこともあり、これらの多くは、小児期〜 思春期に診断される。GDCは腟壁に見られること が多く通常は腟からのアプローチで造袋術や囊胞 摘出術が行われている。今回、下腹部痛を主訴に 受診し、子宮頸部にみられたGDCを腹腔鏡下に摘 出できた症例を経験したので報告する。

\section{症例}

【患者】13歳女性 $157 \mathrm{~cm} \quad 47 \mathrm{~kg}$

\section{【月経歴】初経10歳}

【既往歴】特記すべきことなし。

【現病歴】当院初診 2 年前の秋頃から下腹部痛を 時折自覚した。近医産婦人科で卵巣腫大を指摘さ れ、MRI施行。 $3.8 \times 4 \mathrm{~cm}$ 大の子宮頸部囊胞を認 めた。襄胞部分に一致して圧痛があるため、精 査・加療目的で前医へ紹介となった。

【前医での経過】

腟鏡診で腟内に突出するような所見はなく直腸 診では肛門から $5 \mathrm{~cm}$ ぐらいの所に囊胞をみとめ移 動性は認められなかった。MRIを再検しT2Wで高 信号、子宮頸部内腔との連続性のある $3.8 \times 4 \mathrm{~cm}$ 大の子宮頸部囊胞が認められた（図 1 ）。子宮奇 形は認めず両側卵巣も正常所見で、両側の腎は超 音波で正常所見であり総合的に判断して子宮頸管 
図 1 骨盤MRI T2強調画像

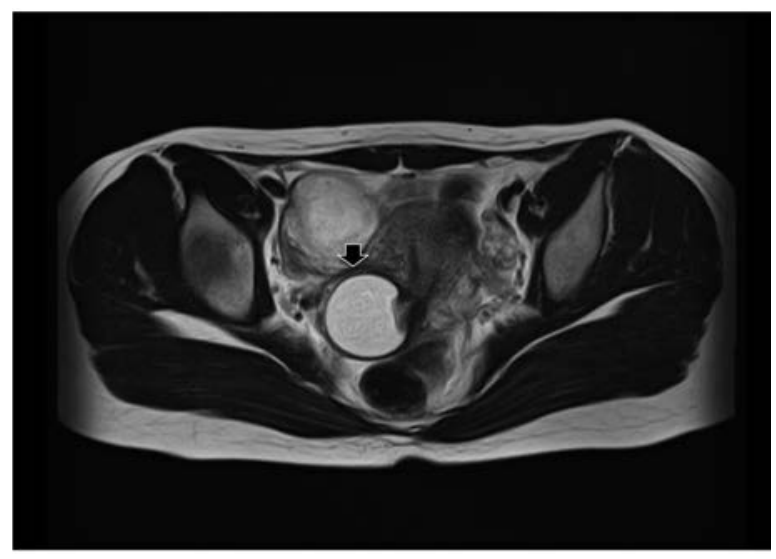

$3.8 \times 4 \mathrm{~cm}$ 大の子宮頸部囊胞（】）で子宮頸部内腔と連続性を認める

内腔に連続性のあるGartner管囊胞（GDC）と診 断された。

痛みが続くため囊胞切除目的で当院初診前年の 3 月に開腹術施行された。囊胞は子宮頸部右下方 の仙骨子宮勒帯上部に認められたが、骨盤底に近 く、手術創に制限があり視野不良であったため摘 出困難と判断され、囊胞の穿刺吸引 (内溶液 $20 \mathrm{ml}$, 細胞診陰性）を行い手術終了となった。術後囊胞 は $1.8 \mathrm{~cm}$ に縮小し、痛みも軽快した。数ヶ月後、 再び痛み増強し、囊胞は $3.3 \mathrm{~cm}$ と増大を認めたた め、腹腔鏡下手術の目的で当科に紹介となった。 【当科での経過】

経直腸的超音波検査で $2.9 \times 3.3 \times 3.1 \mathrm{~cm}$ の囊胞を 認めた（図 2 )。震胞部分に一致して痛みを認め た。月経時に痛みが増強するため低用量ピルで経 過をみたが副作用（うつ様症状）があり中止し、 外科的処置が必要と判断した。

\section{図 2 経直腸超音波所見（襄胞再発時）}

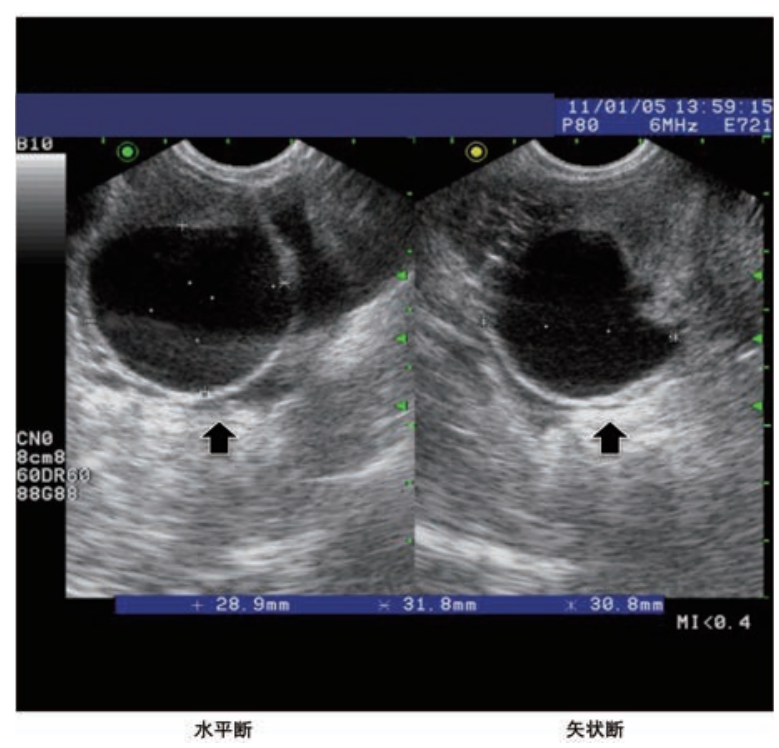

子宮頸部に囊胞を認める
囊胞は子宮頸部から骨盤腔内に突出しているた め腟から行う囊胞摘出や造袋術は不可能と判断し、 腹腔鏡下手術を考慮したが、子宮操作具が 13 歳で 挿入可能か、手術前には評価不明であり、手術が 困難になる可能性も考えられた。そこで、囊胞摘 出が困難な場合は造袋術や硬化療法などの可能性 もあることを説明した。最終的に本人と家族は腹 腔鏡下手術を選択した。

【手術所見】

全身麻酔下に腹腔鏡下手術施行。子宮操作具は 挿入可能であった。右仙骨子宮勒带付着部上部の 子宮頸部に、膨隆する襄胞を認めた（図 3 )。漿 膜を切開し囊胞を露出し、周囲から剥離した（図 4)。子宮頸管との連続部分を切断して震胞を摘 出した。囊胞摘出後、子宮頸管に開口する小孔を 認めた（図 5 )。同部位をまず2-0 PDSで単縫合し さらに周囲の頸部筋層を用いて二層縫合した。（図 $6)$ 。

【病理所見】立方上皮細胞が一層性に並び、繊毛 はみられず悪性所見もなかった（図 7、8）。

\section{図 3 手術所見 (1)}

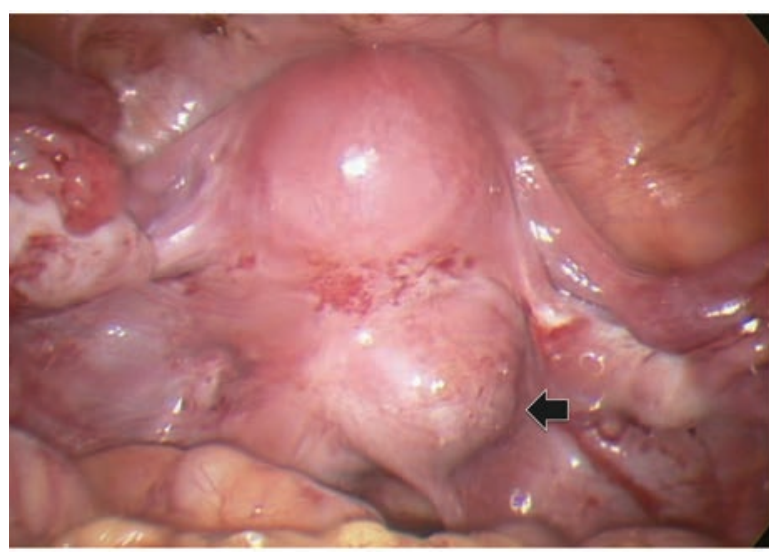

右仙骨子宮勒帯上部に膨隆する囊胞（ヶ

\section{図4手術所見 (2)}

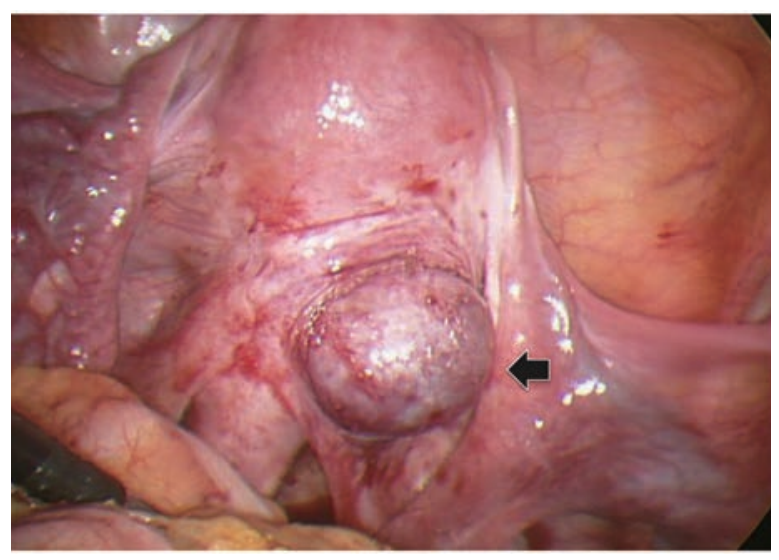

襄胞を露出した所 
図 5 手術所見 (3)

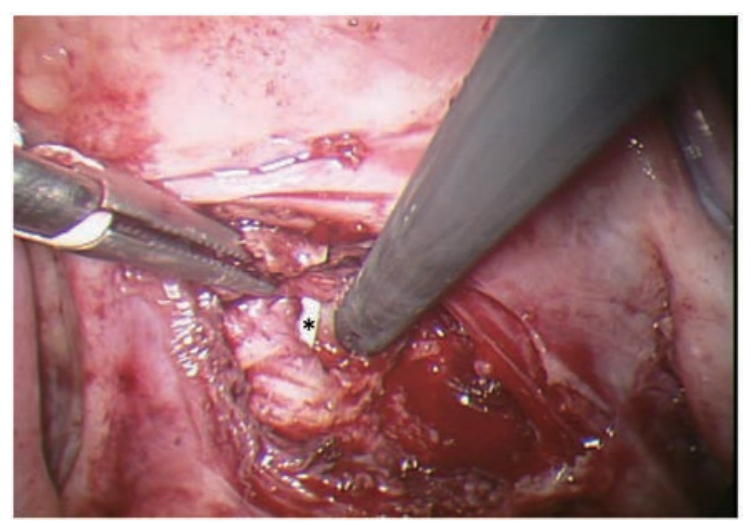

襄胞切除し頸管内のmanipulatorがー部露出 $(*)$

図 6 手術所見 (4)

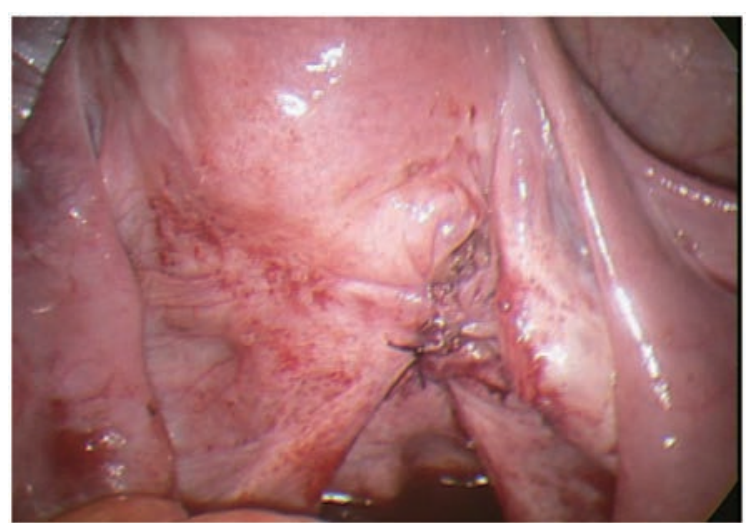

縫合修復後

図 7 摘出標本（肉眼所見）

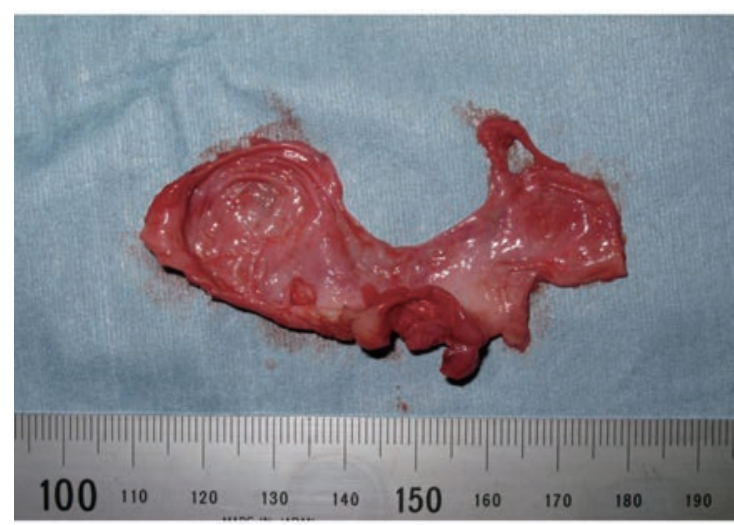

図 8 摘出標本（病理所見）

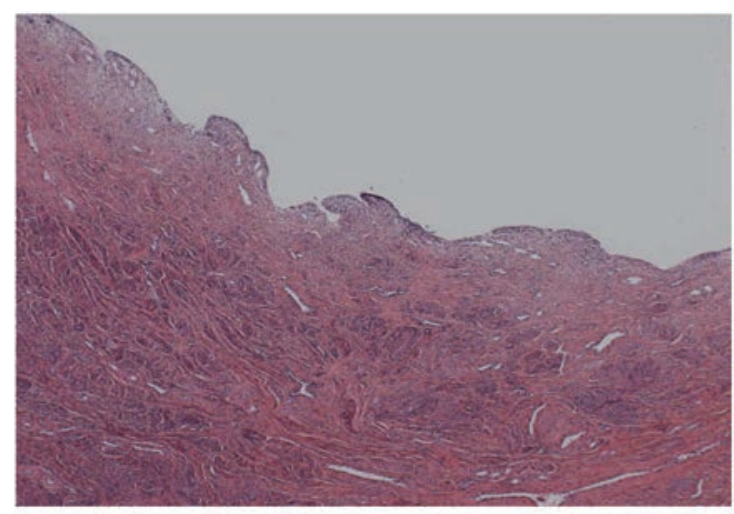

単層立方上皮がみられる
【術後経過】下腹部痛は消失し、術後 4 日目に退 院した。術後11ヶ月時点では経過良好である。

\section{考察}

Gartner管囊胞 (GDC) はWollf管の遺残が囊胞 化したもので、腟側壁に認めるものが多い。胎生 5-8週にかけてのWollf管とMüller管の発生異常に 起因するため、泌尿生殖器の様々な奇形を合併す ることがある。成人女性の約 $25 \%$ にartner管を 認め、その $1 \%$ 年DCとなるといわれている ${ }^{1)} 。$ 囊胞は普通、一つのみで片側性、 $2 \mathrm{~cm}$ 以下であ り、腟壁の近位前外側にみられる。膀胱内に尿管 瘤の様に膨隆したり、外陰部に膨隆することもあ る。通常は無症状でルーチンの検査で見つかるこ とが多いが、囊胞径が大きくなると排尿困難や圧 迫感、帯下、痛みなど様々な症状がみられるよう になる。治療は、経臸的に囊胞穿刺あるいは造袋 術や囊胞摘出術を行う事が多い。

泌尿器系の奇形を合併した例の報告はいくつか みられる。Castagnettiらは、膀胱の背側に $7 \mathrm{~cm}$ の襄胞を認め、左腎欠損のある例で腹腔鏡下に GDC と診断していた ${ }^{2)}$ 。古澤らは、右腎欠損を伴 い感染を繰り返すGDCの例を報告している ${ }^{3)}$ 。 Binsalehらの報告で、新生児期に腟に膨隆する GDCを認めた例では、同側の腎低形成を伴ってい た ${ }^{4)}$ 。また、尿管異所開口を伴ったGDCでは同側 の腎低形成や骨盤腎も認められ、腎および異所尿 管の切除、GDCの摘出術が行われていた ${ }^{5-7)}$ 。GDC に腎低形成を伴う例の約半数に、子宮奇形も合併 したとの報告もある ${ }^{8)}$ 。これらのほとんどで、 GDCについては骨盤内の囊胞あるいは腟壁に膨隆 する囊胞との記載であった。

子宮頸部囊胞という観点から検索すると、子宮 の非対称性の重複奇形に子宮頸部囊胞を認め、同 側の無形成腎を伴う疾患として、Wunderlich症候 群とHernly-Werner 症候群が報告されている ${ }^{9,10)}$ 。 本症例は子宮頸部囊胞を認めたが子宮奇形はなく 両側腎も正常であり、子宮頸部に単独発生した GDCであった。

GDC単独の例としては、繰り返す膿性帯下を認 めた成人女性の 2 例の報告 ${ }^{11)}$ や、妊娠中に骨盤内 囊胞としてみつかった、腟円蓋左外側の $8 \mathrm{~cm}$ 大の GDCの例がある ${ }^{12)}$ 。

GDCは前述したごとく、腟側壁に認められる事 が多く、これらの単独で発生したGDCも含めて治 療は、経腟的に造袋術あるいは囊胞摘出が行われ ているものがほとんどであった。尿管異所開口を 
伴う例では、同時に尿管引き抜き術や無機能腎の 摘出が必要な事もあり、その際に腎摘出に対して 腹腔鏡手術が行われていた。

本症例では、他の泌尿生殖器系の奇形を合併し ないGDCであり、子宮頸部に発生し骨盤腔に突出 する形であったため、部位的に腟からのアプロー チが困難であった。このような症例に対して、腹 腔鏡下手術で囊胞摘出した報告は少ない。

検索し得た範囲で腹腔鏡との関連で報告がある のは、Castagnettiらの、腹腔鏡下にGDCと診断 後、腟的に造袋術を行った例 ${ }^{2}$ 、抢よび古澤らの、 感染を繰り返すGDCを腹腔鏡下に襄胞摘出した例 3)である。

本症例のように、子宮頸部から発生し骨盤腔に 突出するようなGDCの場合は、経胵的アプローチ が困難であり腹腔鏡下手術の適応があると考える。 前医において、開腹術を行ったが䝴胞摘出にいた らなかった事については、開腹創を小さくしてい たため術野の視界が不良で、骨盤底の操作が困難 であった事が理由として挙げられている。

腹腔鏡下手術の利点は、子宮操作具を使用した 場合とくに、子宮の後方の観察に優れているため、 良好な視野で手技を行え、さらに拡大視野で細か い操作が可能である点、また、手術後の負担が少 なく、術後回復が早い点が挙げられる。

また今後考慮する点としては、囊胞切除した際 に子宮頸管へ開口した事である。開口部を縫合し ているため、頸管狭窄を起こす可能性、将来の妊 孕性の問題、分娩方法の選択などが今後の課題で ある。この症例については、まだ中学生であった 事もあり、その点についての説明が不足していた 事が反省点である。今後機会をみて説明をしてい く予定である。

なお、病理学的には、囊胞壁は一層性の立方上 皮であり、中腎管由来の遺残組織と合致してい $た^{13)}$ 。稀にGDCの悪性化の報告もあるが ${ }^{14)}$ 、本症 例では悪性所見はなかった。

\section{【結語】}

腹痛を主訴に発症した子宮頸部のGartner 管囊 胞を腹腔鏡下に切除できた症例を経験した。経腟 的アプローチが困難な場合は経腹的にアプローチ する必要があるが、その場合腹腔鏡下手術により 良好な視野が得られ、囊胞摘出が可能であると考 えられる。

本論文の要旨は第51回日本産科婦人科内視鏡学 会に扔いて発表した。

\section{参考文献}

1 ) Matthew J L, Joseph K VM: Case Report: Gartner's Duct Cyst. Emergency Medicine News 2011; 33(5): 35.

2 ) Castagnetti M, Cimador M, Grazia ED: Diagnostic laparoscopy in a Gartner's duct cyst: Journal of Pediatric Urology 2008 4, 173-175

3 ) 古澤嘉明, 已斐秀樹: 感染を繰り返し、腹腔鏡下に摘 出したGartner震胞の一例、日産婦内視鏡学会誌 2010;26(1):219

4 ) Binsaleh S, Al-Assiri M, Jednak R: Gartner duct cyst simplified treatment approach. Int Urol Nephrol 2007; 39: $485-487$

5 ) 古野剛史, 柿崎秀宏, 柴田隆: 単一異所開脚尿管および 所属腎に対する画像評価と体腔鏡手術、Jpn J Endourol ESWL 2004; 17: 195-199

6 ）河野美幸、福本質置、増山宏明: Gartner 管囊胞を伴 った尿管異所開口に対し尿管引き抜き術を行った 1 例、 J. J. P. U. 2004; 13(2): 51-56.

7 ) Dwyer PL, Rosamilia A: Congenital urogenital anomalies that are associated with the persistence of Gartner's duct: a review. Am J Obstet Gynecol 2006; 195(2): 354-9.

8 ) Sheih CP, Li YW, Liao YJ, et al.: Diagnosing the combination of renal dysgenesis, Gartner's duct cyst and ipsilateral Mullerian duct obstruction. J Urol. 1998; 159: 217-221.

9 ) 福原理恵、福井敦史、藤井俊策: 術前診断が可能であ ったWunderlich症候群の 1 例、青森臨産婦雑誌、 2008; 23(1): 32-6.

10）石橋晶子、藤脇律人、木瀬照康: 異なる臨床経過を呈 したWunderlich症候群の 2 症例、産婦中四会誌、 2007; 55(3): 12-16.

11) Emmons SL,Petty WM: Recurrent giant Gartner's duct cysts. A report of two cases. J Reprod Med. 2001 Aug; 46(8): 773-5.

12) AV Arumugam, G Kumar, LK Si et. al: Gartner duct cyst in pregnancy presenting as a prolapsing pelvic mass Biomed Imaging Interv J 2007; 3(4): e46.

13）藤原潔: Mesonephric duct に由来する病変の病理、病 理と臨床、2002; 20(11): 1156-60.

14) Bats AS, Metzger U, Le Frere Belda MA: Malignant transformation of Gartner cyst. Gynecol Cancer. 2009 De; 19(9): 1655-7 